\title{
Features of the Investor State Dispute Settlement (ISDS) Provisions under Bilateral Investment Treaties (BITs) of Bangladesh: An Overview
}

\author{
Dr. Rumana Islam*
}

\section{Introduction}

The world politics during 1960s till early 1990s is marked by different events and dramatic changes in world economy, trade and flow of foreign direct investment (FDI) with the impacts of cold-war, expansion of communism, protectionism towards foreign investment, state policy of nationalization of natural resources sector in the newly emerged independent states and later the proliferation of globalization in a bipolar word. However due to the decline and fall of communism in former Soviet Union and the world becoming a more unipolar in absence of a strong and influencing communist bloc, the early 1990s was the perfect time for expanding the Western agenda of proliferation of the bilateral investment treaty (BIT) program which was once initiated by the then West Germany in $1959 .{ }^{1}$ The early 1980 s and the post-communist era is also marked as the period as a universal acknowledgement that, 'capitalism and private ordering are superior to socialism and state ownership of production." 2 This also reflected in the change of attitude towards the BIT program by different countries, and even those countries, especially the Latin American countries which once were opposing the idea of BIT programs and any international settlement of disputes through an arbitral tribunal against the host state ${ }^{3}$. Such change of attitude is well described by Ranjan who states that,

...many countries saw BITs as a commitment to liberal economic policies and as instruments that could further the objectives of a liberal foreign investment regime and lead to greater investment flows especially into developing countries. Bilateral Investment Treaties signed during this period followed a neoliberal template that favoured a minimalist state. Thus, these treaties (also known as the first generation of BITs) contained very broad and substantive guarantees to foreign investors with limited or no provisions recognizing host state's right to regulate in public interest. ${ }^{4}$ [footnotes in the original text omitted]

Professor, Department of Law, University of Dhaka, email: rumana.law@du.ac.bd

1 Prabhash Ranjan, India and Bilateral Investment Treaties: Refusal, Acceptance, Backlash (Oxford University Press 2019) 5.

2 Ranjan, ibid, citing, Jonathan R. Macey and Geoffery P. Miller 'The End of History and the New World Order: The Triumph of Capitalism and the Competition between Liberalism and Democracy' (1992) 25 Cornell International Law Journal 275, 283.

3 See M. Sornarajah, International Law on Foreign Investment Law $\left(3^{\text {rd }} \mathrm{edn}\right.$, Cambridge University Press 2010) 183-187.

$4 \quad$ Ranjan (n 1) 8. 
As an impact of this liberalization towards foreign investment and proliferation of BITs and with the expansion of globalization the flow of FDI from the North to the South increased as a natural outcome. With the increase of flow FDI from the capital exporting countries to capital importing countries which are mostly the developing countries, the number of investor state dispute settlement (ISDS) also has significantly risen on global scale. ${ }^{5}$ The ISDS is basically done in two ways, either by inserting an ISDS clause in the particular Bilateral Investment Treaty (BIT) or multilateral treaties between two contracting countries and in absence of any such BITs or other investment treaties, by the parties inserting such an arbitration clause in joint venture agreement (JVA) concluded between the foreign investor and host state or its state enterprises. One core reason for the proliferation of BIT program by the capital exporting countries was to make the ISDS an integral part of the BITs. The idea of having an option for ISDS was done with an aim that this mechanism would give the foreign investors the right to bring any allegation of breach of committed standards of protection in those BITs against the host states or any unreasonable interference amounting to expropriation (both direct or indirect) or for a regulatory measures taken by the host state affecting those investment protection standards.

Except very few exceptions the ISDS provision is a common feature appearing in almost every BITs that exists today. Though the forums ( $a d$ hoc or institutional) that the parties select for such investor state dispute resolution and their preference over each other (the forums) and the relations between these forums and the exceptions of specific issues as prescribed in the BITs either devised as essential security interest or general exceptions or non-precluded measures (NMPs) from the ambit of the ISDS clauses largely varies on the different articulations of those ISDS provisions.

Thus, with the proliferation of the BIT programs the ISDS provisions also became a core feature of international investment law. Though many states argued that all claims against the host state must be dealt by the local courts instead in an international for, but very few BITs actually provided in their ISDS clause an option for local remedies that the foreign investors must exhaust before bringing a claim against the host state in an international forum. ${ }^{6}$ In majority of these BITs the ISDS as they are drafted provide unequivocal consent to arbitration to foreign investors. ${ }^{7}$ Since the sole purpose of BIT program initiated by the West was for with an aim to

See e.g., UNCTAD Report on ISDS <https://unctad.org/system/files/official-document/diaepcbinf 2020d6.pdf > accessed 1 November 2020>

6 Rudlof Dolzer and Christoph Scheruer, Principles of International Investment Law (Oxford University Press 2008) 265; Also see e.g. Helnan International Hotels A/S v. Arab Republic of Egypt, ICSID Case No. ARB/05/19, Decision on Annulment, 14 June 2010, paras 43-57; General Ukraine Inc v Ukraine, ICSID Case No. ARB/00/9, Award 16 September 2003, para 13.4.

7 Ranjan (n 1) 2; Also see, Christoph Scheruer 'Consent to Arbitrate' in Muchlinski, Freericoe Ortino and Christoph Schreur (eds), The Oxford Handbook of International Investment Law (Oxford University Press 2008) 835-6. 
provide maximum protection to foreign investors, this is also reflected in the ISDS clauses stipulated in the BITs, that ensures that the host states can be charged responsible for the exercise of their public power by a third party-the international tribunals, which has the power to reassess the regulatory actions taken by the host state, including all kinds of powers that a state can exercise through its state organs-the executive, judicial or legislative. ${ }^{8}$ It is also relevant to mention that, the ISDS provisions in the BITs exist along with the State-Sate Dispute settlement (SSDS) provisions that allows the contracting parties to bring cases against each other. However, unlike ISDS, the SSDS does not concern settlement of a dispute regarding violation or breach of a treaty obligation, rather, it concerns the 'interpretation or application' of the treaty. ${ }^{9}$ Therefore the ISDS and SSDS have different mandates. ${ }^{10}$

With this contextual background of the BITs concluded between the developed countries and developing countries and the purpose of inserting an ISDS clause, this article will make a close examination of the ISDS provisions under the BITs of Bangladesh to see how these clauses are articulated and find out the features of these clauses that can be summarized based on an overarching similarities between these clauses and also to find out to what extent such clauses provide for regulatory freedom for Bangladesh as the host state when read with other provisions of the BITs.

\section{Features of ISDS Provisions of BITs of Bangladesh}

The common features that, the BITs include in their ISDS clause are the forums for the dispute settlement, if there is any alternative to dispute settlement (like mediation or conciliation) or if there is any scope to refer the dispute to the domestic courts or any requirement of exhausting of local remedies before going to an international forum. Apart from these there might be also other specific ISDS features contained in the particular clause in the BITs. These are not common to every BITs, by can be randomly found in different BITs. Therefore, these features do not include a generic feature of ISDS provisions. These other specific features include, provisions such as limitation period for submission of the claims for disputes, if any provisional measures is required power to do so, consolidation of claims, limiting the types of the remedies that can be available through the Award( parties sometimes specify available types of remedies), provisions on treaty interpretation-this is sometimes also refereed to joint committee of the parties if limits issues to be submitted by the

8 Ranjan (n 1) 3; Also see e.g., Andreas Kullick, Global Public Interests In International Investments Law (Cambridge University Press 2012) 93; Also see generally e.g., Stephen W. Schill, Multilateralization of International Investment Law (Cambridge University Press 2009).

9 Ranjan (n 1) 2. Also see e.g., Republic of Italy v Republic of Cuba, Final Award, Ad Hoc Tribunal, 15 January 2008.

10 Ranjan ibid. 
contracting parties before the tribunal (renvoi), provisions regarding regulating submissions by non-disputing State parties, requirement of transparency in arbitral proceedings, whether the documents can be made publicly available, provisions as to whether hearings of the proceedings are to be open to the public, provisions regarding amicus curiae submissions by third (non-disputing) parties.

Just after Bangladesh had enacted it's The Foreign Private Investment (Promotion and Protection) Act, $1980^{11}$ keeping pace with trend of the developing countries it also resorted to signing of BITs to promote flow of FDIs with different countries. These BITs were typically seen by the developing countries to be the conducive that foreign investors liked to have for their protection. ${ }^{12}$ As to the total number of BITs signed by Bangladesh the UNCTAD's Investment Policy Hub website, shows in its Bangladesh BIT profile that, the country has signed 30 BITs with 28 countries. ${ }^{13}$ Though the other available information on the number of BITs signed by Bangladesh for example the Bangladesh Investment Development Authority (BIDA) websites ${ }^{14}$ shows different number but the BIDA website does not provide the text of the BITs nor any kind of information on the additional BITs that it mentioned by BIDA could be located elsewhere, this article will rely on the information provided by UNCTAD's Investment Policy Hub website and endeavor to examine those listed BITs.

With only two exceptions, namely the Bangladesh-Germany BIT (1981) ${ }^{15}$ and Bangladesh-Republic of Korea BIT $(1986)^{16}$ every BIT signed by Bangladesh predominantly provides for an enforcement mechanism of ISDS, generally conferring the rights of the foreign investors to have the right to take the recourse to

11 See <http://bdlaws.minlaw.gov.bd/act-597.html> accessed 1 November 2020.

12 On proliferation of BIT program see generally Kenneth J. Vandevelde, 'The Political Economy of a Bilateral Investment Treaty' (1998) 92(4) The American Journal of International Law 621-641; Kenneth J. Vandevelde, 'U.S. Bilateral Investment Treaties: The Second Wave' (1993) 14 Michigan Journal of International Law 621.

13 See e.g., <https://investmentpolicy.unctad.org/international-investment-agreements/countries/16/ bangladesh> accessed 1 November 2020.

14 See e.g., <http://bida.gov.bd/?page_id=2552> accessed 1 November 2020. The BIDA website refers to a Bangladesh-Belarus BIT. But the only information available information found is that, Bangladesh has signed a MOU with Belarus on agriculture and food, see <https://www.thedailystar.net/news-detail-235653> accessed 14 October 2020 and has signed an Agreement on Trade and Economic Cooperation, see e.g., <http://mfa.gov.by/en/press/news_mfa/ e33df1a3af362d77.html> accessed 14 October 2020.

15 Agreement between the Federal Republic of Germany and the People's Republic of Bangladesh concerning the Promotion and Reciprocal Protection of Investments [hereinafter BangladeshGermany BIT (1981)] signed $6^{\text {th }}$ May, 1981 and came into force on $14^{\text {th }}$ September 1986 . For full text of the BIT see e.g., <https://investmentpolicy.unctad.org/international-investment-agreements/ treaty-files/264/download $>$ accessed 1 November 2020.

16 Bangladesh-Republic of Korea BIT (1986) singed on $18^{\text {th }}$ June 1986 and came into force on $6^{\text {th }}$ October, 1988. For full text see e.g., <https://investmentpolicy.unctad.org/international-investmentagreements/treaty-files/270/download> accessed 1 November 2020. 
international arbitration against Bangladesh on different forums by sidestepping the country's domestic court system. Apart from the ISDS the BITs of Bangladesh also provide provisions for subrogation, settlement of disputes between the contracting parties and practical matters regarding the treaties such as when they shall come into force, its duration, its termination, provision on different investment protection standards like the fair and equitable treatment (FET) standard, the most favored nation (MFN) treatment standard, national treatment (NT) standard, protection against expropriation, to lesser degree some NPMs, the definition of an investment under the BIT and some also provide the procedure of its amendment if any. The majority of the BITs in Bangladesh reflects the typical template of most developing countries, or better to say the first general of BITs concluded between the developed countries and the developing countries which were actually designed to provide maximum protection for the foreign investors. This was the predominant perception of the function of the BITs that once shaped the international legal regime of law on foreign investment during the post WWII till late nineties. Though it is always debated to the extent how far these BITs have contributed and will contribute to increase the FDI influx into the country is doubtful.

The following part of the article will provide an overview of the features of the ISDS provisions in the existing BITs of Bangladesh as they have been articulated. Some of them have uniformity though they largely differ on their verbalisation. Some of these provisions are all comprehensive ISDS clause while some have preferred to adopted only few selected forums. The discussion is periodized in chronological order into four decades staring from 1980 when Bangladesh signed its first BIT.

\subsection{BITs of the First Decade (from 1980-1990)}

During the first decade Bangladesh signed nine BITs, mostly with capital exporting Western countries. Apart from the two BITs signed during this period, namely Bangladesh-Germany BIT (1981) and Bangladesh-Republic of Korea BIT $(1986)^{17}$, the rest others has ISDS provisions.

Bangladesh-UK BIT $(1980)^{18}$ is the first BIT signed by Bangladesh with its former colonial power. Also interesting it is the only BIT signed by Bangladesh which came into force the very moment it was singed. Article 8 of the BIT under the heading 'Reference to International Center for Settlement of Investment Disputes"

17 Bangladesh-Republic of Korea BIT (1986) singed on $18^{\text {th }}$ June 1986 and came into force on $6^{\text {th }}$ October, 1988. For full text see e.g., <https://investmentpolicy.unctad.org/international-investmentagreements/treaty-files/270/download> accessed 1 November 2020.

18

Agreement between the Government of the United Kingdom of Great Britain and Northern Ireland and the Government of the People's Republic of Bangladesh for the Promotion and Protection of Investments signed on $19^{\text {th }}$ June 1980 and came into force on the same day. See, $<$ https://investmentpolicy.unctad.org/international-investment-agreements/treaty-files/277/download $>$ accessed 1 November 2020. 
refers thereby as the heading suggests only to International Center for Settlement of Investment Disputes (ICSID) for ISDS. There is no mention of any other features of the ISDS provisions and nor does the BIT provide any regulatory freedom or policy exception for ISDS brought by the foreign investors. Similar provision is stipulated in Bangladesh-BLEU (Belgium-Luxembourg Economic Union) BIT $(1981)^{19}$ in its Article 6 referring only to ICSID as the forum of ISDS under the treaty. However, the Bangladesh-BLEU (1981) BIT does also in its Article 6(1) refer to voluntary ADR by way of mediation and conciliation as an alternative to ISDS. It is also to be noted that, Article 6(1) categorically mentions that all kinds of disputes covered under the treaty can be brought before ICSID except 'matters relating to tax disputes'. Therefore, this is the only limitation for investors to bring a claim against the host state to ISDS under the treaty. Bangladesh-US BIT $(1986)^{20}$ in its Article VII deals with ISDS provisions, which also prescribes voluntary ADR (conciliation/mediation) alternative to arbitration. The prescribed forums are the local courts and ICSID and the relationship between these two forums are 'fork on the road'. The text of Bangladesh-France BIT $(1985)^{21}$ in its Article 8 prescribes for two forums, the local courts and ICSID without providing any reference to the relation between these two forums, as well as it prescribes for voluntary ADR as an alternative to ISDS. ${ }^{22}$ Bangladesh-Turkey BIT $(1987)^{23}$ prescribed in its Article VI, the only forum for

19 Bangladesh BLEU BIT (1981) signed on $22^{\text {nd }}$ May 1981 and came into force on $15^{\text {th }}$ September 1987. For full text see e.g., <https://investmentpolicy.unctad.org/international-investmentagreements/treaty-files/262/download> accessed 1 November 2020.

20 Bangladesh-US BIT (1986) signed on $12^{\text {th }}$ March 1986 and came into force on $25^{\text {th }}$ July 1989 . For full text see e.g., <https://investmentpolicy.unctad.org/international-investment-agreements/treatyfiles/278/download> accessed 1 November 2020.

21 Bangladesh-France BIT (1985) signed on $10^{\text {th }}$ September 1985 and came into force on $9^{\text {th }}$ October 1986. see e.g., <https://investmentpolicy.unctad.org/international-investment-agreements/treatyfiles/263/download> accessed 1 November 2020. Article 8 of Bangladesh-France BIT (1985) states,

"1. Any dispute relating to an investment shall be raised by the investor of one Contracting Party to the other Contracting Party by written notification accompanied by a sufficiently detailed request. Such a dispute is preferably settled by amicable arrangement between the parties to the dispute or, in the event of failure, by internal appeal, by conciliation between the Contracting Parties through the diplomatic channel or by any other means.

2. In the absence of agreement between the parties to the dispute, within six months of the date of its notification, the dispute is, at the request of either of the two parties concerned, submitted to the International Center for Settlement of Investment Disputes (hereinafter referred to as "the Center"), established by the Convention for the Settlement of Investment Disputes between States and nationals of other States, signed in Washington on March 181965.

For this purpose, each Contracting Party agrees to submit such a dispute to the Center.

3. A Contracting Party to a dispute may not, at any stage of the conciliation or arbitration procedure or of the execution of the arbitral award, object to the fact that the national or the company party to the dispute under insurance, compensation for all or part of the losses."

Bangladesh-Turkey BIT (1987) signed on $12^{\text {th }}$ November 1987 and came into force on $21^{\text {st }}$ June 1990. For full text see e.g., <https://investmentpolicy.unctad.org/international-investmentagreements/ treaty-files/277/download> accessed 1 November 2020. 
ISDS is ICSID, however this is replaced by the Bangladesh-Turkey BIT (2012) ${ }^{24}$ which is yet to come into force. The 1987 BIT with Turkey is distinct from the rest other BITs signed during this decade as it is the only one and the first one for Bangladesh which provided public policy areas excluded from ISDS claims in its Article X, which reads as

1. This agreement shall not preclude the application by either Party of measures necessary for the maintenance of public order and morals, the fulfilment of its obligations with respect to the maintenance or restoration of international peace or security, or the protection of its own essential security interests.

As it will be seen later part of the discussion this exclusion of public policy areas from ISDS is not reflected in most of the BITs signed by Bangladesh.

Bangladesh-Romania BIT $(1987)^{25}$ is an interesting one. The treaty does not provide a separate clause on ISDS like other BITs, but it prescribes the scope of ISDS only in the occasion of expropriation under its Article 4 which is titled as "Expropriation and Compensation", therefore making the scope of ISDS under this treaty a very limited one. Article 4 (2) \& (3) reads as follows:

(2) If a dispute between an investor and the Contracting Party in the territory of which the investment has been made, with regard to the amount of compensation, continues to exist after the final decision of the national tribunal or of another competent body in the country in which the investment has been made, either of them is entitled to submit the dispute, for conciliation or arbitration, within two months after the exhaustion of domestic remedies or after the Expiry of the term provided on the next paragraph, to the International Centre for the Settlement of Investment Disputes, according to procedure provided for in the Convention opened for signature at Washington On 18 March 1965.

(3) However, the condition relating to the exhaustion of the ways of remedies provided for in the legislation of the Contracting Party in the territory of which the investment has been made, cannot be opposed by this Contracting Party to the investor of the other Contracting Party after a term of six months running from the date of the first act of judicial procedure for the settlement of this dispute by the tribunal."

Therefore, this BIT is unique in the sense that an investor can bring a claim for ISDS before ICSID only in the event of expropriation and that too is subject to certain limitations set forth in Article 4 described above and also subject to exhaustion of

24 Bangladesh-Turkey BIT (2012), signed on $12^{\text {th }}$ April 2012, replaced Bangladesh-Turkey BIT (1987); for full text of Bangladesh-Turkey (2012) BIT see e.g., <https://investmentpolicy.unctad.org/ international-investment-agreements/treaty-files/274/download> accessed 1 November 2020. 
local remedies. Therefore, this BIT does not have ISDS clause separately but prescribes the local courts and ICSID as forums only limited to expropriation claims.

The Bangladesh-Italy BIT $(1990)^{26}$ is the only BIT so far signed by Bangladesh under which a claim was brought by the investor against Bangladesh in ICSID. ${ }^{27}$ Article 9 of the BIT deals with ISDS provisions. In Article 9(1) is provides limitation of provisions subject to ISDS, as it states, “... relating to compensation for expropriation, nationalization, requisition or similar measures including disputes relating to the amount of the relevant payments...". Article 9(2) refers to domestic courts, UNCITRAL and ICSID as forums for ISDS, without any reference to relationship between these forums.

\subsection{BITs of the Second Decade (from 1991-2000)}

During this decade the country went through significant political change, when the long military dictatorship was overthrown from power as a result of political uprising against the regime and the country entered into its current 'democratic phrase' through a general election held in December, 1991. However, during this period, the two regimes that was in power through the 1991 and 1996 general elections, have concluded in total eleven BITs, all having provisions for ISDS in almost similar verbatims but also variant in terms of giving an advantage or imposing limitations upon the investors or the host state. Bangladesh-Netherlands BIT $(1994)^{28}$ in its Article 9 provides ICSID as the only forum for ISDS. The clause is a very short one and does not provide any other reference to any general or specific features of ISDS provisions. Article 6 of Bangladesh-Malaysia BIT $(1994)^{29}$ prescribes only ICSID as the venue for conciliation or arbitration. One interesting point is in Article 6(3) (iii) which states that,

In the event of disagreement as to whether conciliation or arbitration is more appropriate procedure, the opinion of the investor concerned shall prevail. The Contracting Party which is a party to the dispute shall not raise as an objection, defense or right of set-off at any stage of the proceedings or enforcement of an award the fact that the investor which is the other party to the dispute has received or will receive, pursuant to an insurance or guarantee contract, an indemnity or other compensation for all or part or its losses and damages. [emphasis added]

26 Bangladesh-Italy BIT (1990) signed on $20^{\text {th }}$ March 1990 and came into force on $20^{\text {th }}$ September, 1994. For full text of the BIT see .e.g., <https://investmentpolicy.unctad.org/internationalinvestment-agreements/treaty-files/268/download> accessed 1 November 2020.

27 Saipem S.p.A. v. People's Republic of Bangladesh (ICSID Case No. ARB/05/7) Award dated 30 ${ }^{\text {th }}$ June, 2009. For text of the Award see, e.g., <https://www.italaw.com/sites/default/files/casedocuments/ita0734.pdf > accessed 13 October 2020.

Bangladesh-Netherlands BIT (1994) signed on $1^{\text {st }}$ November, 1994 and came into force on $1^{\text {st }}$ June 1996. For full text see e.g., <https://investmentpolicy.unctad.org/international-investmentagreements/treaty-files/271/download> accessed 1 November 2020. agreements/treaty-files/5126/download> accessed 1 November 2020. 
Thereby Article 6(3) (iii) of the aforesaid Bangladesh-Malaysia BIT (1994) gives the investor an advantage to choose the appropriate forum that it might think appropriate to bring a dispute against the host state.

On the other hand, Bangladesh-China BIT $(1996)^{30}$ rather imposes a restriction upon the investors on specific matters. In its Article 9, the BIT prescribes forums such as domestic courts, ad hoc tribunals and ICSID referred to sub-clause 2 to 4 . of Article 9. Article 9(3) puts an embargo upon the investor stating that,

If a dispute involving the amount of compensation for expropriation cannot be settled within six months after resort to negotiations as specified in paragraph 1 of this Article, it may be submitted at the request of either party to an ad hoc arbitral tribunal. The provisions of this paragraph shall not apply if the investor concerned has resorted to the procedure specified in the paragraph 2 of this Article. [emphasis added]

Article 9(2) states that, if the dispute between the investor and the state cannot be settled through, negotiations it shall be entitled to submit to the local courts. Therefore Article 9(2) and (3) read together implies that, once a dispute concerning amount of compensation or expropriation has been submitted before the domestic courts, the investor is barred from initiating an arbitration procedure on these two matters. Article 9(4) also prescribes the appointment procedure of arbitrators of the tribunal.

Bangladesh-Poland BIT $(1997)^{31}$ in its Article 7 stipulates ISDS and prescribes forums such as the ad hoc tribunals established under UNCITRAL rules, ICSID and as well as other forums in its Article 7(2), particularly mentioning the "a court of arbitration in accordance with the Rules of Procedure of the Arbitration Institute of the Stockholm Chamber of Commerce," and "the court of the arbitration of the Paris International Chamber of Commerce". Article 7 does not mention the relationship between these forums. It is also to be noted the limitation provided in Article 7(5) of the BIT upon the host state, which reads as follows:

The Contracting Party which is a party to the dispute shall at no time whatsoever during the procedures involving investment disputes, assert as a defense its immunity or the fact that the investor has received compensation under an insurance contract covering the whole or part of the incurred damage or loss. [emphasis added]

30 Bangladesh China BIT (1996) signed on $12^{\text {th }}$ September, 1996 and entered on $25^{\text {th }}$ March 1997. The full text of this BIT is not publicly available. However, it is available only for the subscribers to Investment Claims, e.g. <https://oxia.ouplaw.com > 12 October 2020..

31 Bangladesh-Poland BIT (1997) signed on $8^{\text {th }}$ July 1997 and came into force on $19^{\text {th }}$ November 1999. For full text of the BIT see e.g., <https://investmentpolicy.unctad.org/international-investmentagreements/treaty-files/5127/download>accessed 1 November 2020. 
Bangladesh-Japan BIT (1998) ${ }^{32}$ provides in its Article 10 ISDS along with voluntary ADR (conciliation/mediation). Article 10 also refer two forums for ISDS, the domestic courts of the host state and ICSID and requires in Article 10(3) that local remedies must be exhausted before going to the international forum for arbitration suggesting, that the relation between the two forums are 'fork on the road' ${ }^{33}$ Signed in the same year, similar verbatim appears Article VIII of Bangladesh-Indonesia BIT $(1998)^{34}$ which refers to voluntary ADR (conciliation/mediation) and prescribing two forums for ISDS in its Article VIII (3)- domestic courts and ICSID, but does not mention the relationship between these two forums like that of Bangladesh-Japan BIT (1998). Exactly similar provision like the Bangladesh-Indonesia BIT (1998) is found in Bangladesh-Philippines BIT $(1997)^{35}$ in its Article IX. ${ }^{36}$

Bangladesh-Democratic Republic of Korea BIT (1999) ${ }^{37}$ even after two decades of its signing is yet to come into force. Article $7^{38}$ of the BIT deals with ISDS provision. Drafted perhaps in the bluntest verbal it does not provide any alternatives to arbitration and the domestic courts as the only means of resolving a dispute between an investor and the host state. This is the only BIT which does not provide any other forum apart from the domestic courts. This makes this particular ISDS provision a distinct one.

32 Bangladesh-Japan BIT (1998) signed on $10^{\text {th }}$ November, 1998 and came into force $25^{\text {th }}$ August 1999. For full text see e.g., <https://investmentpolicy.unctad.org/international-investment-agreements/ treaty-files/269/download $>$ accessed 1 November 2020.

33 Therefore Article 10(3) of the Bangladesh- Japan BIT (1998) reads as follows:

"So long as and investor of either Contracting Party is pursuing administrative or judicial settlement within the territory of the other Contracting Party concerning a dispute that may arise out of investment made by such investor, or in the event that a final judicial settlement on such dispute has been made, such dispute shall not be submitted to arbitration referred to in the provisions of the present Article."

Bangladesh-Indonesia BIT (1998) singed on $9^{\text {th }}$ February 1998 and came into force on $22^{\text {nd }}$ April, 1999, for full text see e.g., <https://investmentpolicy.unctad.org/international-investmentagreements/treaty-files/266/download> accessed 1 November 2020.

Bangladesh-Philippines BIT (1997) singed on $8^{\text {th }}$ September, 1997 and came into force on $1^{\text {st }}$ August 1998, for full text see e.g., <https://investmentpolicy.unctad.org/international-investmentagreements/treaty-files/272/download> accessed 1 November 2020.

36 Article IX of Bangladesh-Philippines BIT (1997) ibid, refers two forums for ISDS, namely the domestic courts and ICSID but without prescribing the relation between these two forums. It does not contain any other common features or special features of ISDS provisions

37 Bangladesh-Democratic Republic of Korea BIT (1999), signed on $21^{\text {st }}$ June 1999, for full text see e.g., <https://investmentpolicy.unctad.org/international-investment-agreements/treaty-files/5128/ download> accessed 1 November 2020.

38 Article 7 of Bangladesh- Democratic Republic of Korea BIT (1999) states,

“(1) Any dispute which may arise between investor of one Contracting Party and other Contracting Party in connection with investment shall, as far as possible, be settled amicably through consultations between the parties to the dispute.

(2) If these consultations do not result in a solution within six month from the date of the request for settlement, the investor shall be entitled to submit the case to the competent court of the Contracting Party in the territory of which the investment has been made". 
In the year 2000, Bangladesh singed three BITs. Article 8 of BangladeshSwitzerland BIT $(2000)^{39}$ and Article 10 of Bangladesh-Uzbekistan BIT (2000) ${ }^{40}$ contains almost wordings on provision on ISDS mechanism under the aforesaid BITs prescribing ICSID as the only forum. ${ }^{41}$ The Bangladesh-Austria BIT $(2000)^{42}$ is different from rest other BITs, so far singed by Bangladesh; as rather than a single Article or clause this BIT has separate chapter to elaborately deal with different issues related to investment between the two contracting parties. Accordingly, Chapter Two, Part One of the BIT (from Articles 11-17) deals with ISDS, each Article different aspects of the ISDS mechanism. ${ }^{43}$ As forums for ISDS in its Article 12 it refers to all the possible recourse, i.e. domestic courts, ICSID, UNCITRAL and other forums (ICC). As regards relationship between the forums in its Article 12 (1) (a) and (b) it prescribes for preserving right to arbitration after domestic court proceedings. This BIT also contains a special feature of ISDS which states a limitation period of 60 days for submission of claims in its Article 12 (2). Article 17 of the BIT also contains specialty as it makes an elaborate description of the scope of the Awards. ${ }^{44}$ Article 17(1) (c) provides for restitution in kind in appropriate cases. Other BITs signed by Bangladesh do not prescribe such elaborate provision on Awards and enforcement.

39 Bangladesh-Switzerland BIT (2000) signed on $14^{\text {th }}$ October, 2000 and came into force on $3^{\text {rd }}$ September 2001. The BIT is available in both French and English. For full text of the BIT in English see, e.g. <https://investmentpolicy.unctad.org/international-investment-agreements/treaty-files/4807/ download> accessed 1 November 2020.

40 Bangladesh-Uzbekistan BIT (2000) signed on $18^{\text {th }}$ July 2000 and came into force on $24^{\text {th }}$ January 2001. For full text of the BIT see e.g., <https://investmentpolicy.unctad.org/international-investmentagreements/treaty-files/279/download> accessed 1 November 2020.

41 Article 8(2) of Bangladesh-Switzerland BIT (2000) prescribes for voluntary ADR (conciliation/ mediation) as an alternative to arbitration.

42 Bangladesh-Austria BIT (2000) signed $21^{\text {st }}$ December 2000 and came into force $1^{\text {st }}$ December 2001. For full text see e.g., <https://investmentpolicy.unctad.org/international-investment-agreements/ treaty-files/z170/download> accessed 1 November 2020.

43 Each Articles under Chapter Two, Part One deals with different issues, these are namely, Article 11 (scope and standing), Article 12 ( Means of Settlement, time period), Article 13 (contracting party consent), Article 14 (place of arbitration), Article 15 (indemnification), Article 16 (Applicable law) and Article 17 (Awards and Enforcement). It does not provide any policy exception clause for ISDS nor does prescribe for any alternative to arbitration

44 Article 17 (1)of Bangladesh-Austria BIT (2000) reads as follows:

"(1) Arbitration awards, which may include an award of interest, shall be final and binding upon the parties to the dispute and may provide the following forms of relief:

(a) a declaration that the Contracting Party has failed to comply with its obligations under this Agreement;

(b) pecuniary compensation, which shall include interest from the time the loss or damage was incurred until time of payment;

(c) restitution in kind in appropriate cases, provided that the Contracting Party may pay pecuniary compensation in lieu thereof where restitution is not practicable; and

(d) with the agreement of the parties to the dispute, any other form of relief." 


\subsection{BITs of the Third Decade (from 2001-2010)}

During this period Bangladesh signed six BITs, some of which have certain distinctive features of their own. For example, Bangladesh-Islamic Republic of Iran BIT $(2001)^{45}$ is the only BIT which starts with 'In the name of God". Article 13 of the Bangladesh-Iran BIT (2001) prescribes for ISDS. This Article does not refer to any forums of ISDS like other BITs, rather it is left open for the parties to decide how they are going to appoint the arbitrators to form a tribunal for settling the dispute between the investor and the host state. It further stipulates that if the parties fail to appoint an arbitrator then the parties can make a request to President of the International Court of Justice to appoint an arbitrator. Another interesting part of Article 13(1) is, it states, ".... However, the umpire shall be a national of a state having diplomatic relation with both Contracting Parties". Therefore, there is a nationality embargo in appointing arbitrator under this BIT in terms of diplomatic relation with both contracting parties.

Bangladesh-Thailand BIT $(2002)^{46}$ provides ISDS mechanism in its Article 9 and as forums for arbitration it provides for the domestic courts of the host state and adhoc tribunals established under UNCITRAL rules without mentioning any reference to the relation between these two prescribed forums. It is also noteworthy that it does not refer to ICSID which is bit unusual, the reason might be that, though Thailand had signed the ICSID Convention in 1985, but it is yet to ratify the Convention. ${ }^{47}$ Though India never even signed the ICSID Convention but Bangladesh-India BIT $(2009)^{48}$ does mention, ICSID as a forum for ISDS. This clause does not refer to other specific features of ISDS, but Article 9(3) is of particularly noteworthy, which states:

3. The arbitral tribunal established under this Article shall reach its decision on the basis of national laws and regulations of the Contracting Party, which is a party to the dispute, the provisions of the present Agreement, as well as applicable rules of international law. [emphasis added]

45 Bangladesh-Iran BIT (2001) signed on $29^{\text {th }}$ April 2001 and came into force on $5^{\text {th }}$ December 2002. For full text of the BIT see e.g. <https://investmentpolicy.unctad.org/international-investmentagreements/treaty-files/267/download> accessed 1 November 2020.

46 Bangladesh-Thailand BIT (2002) signed on $9^{\text {th }}$ June 2002 and came into force on $12^{\text {th }}$ January 2003. This 2002 BIT replaced Bangladesh-Thailand BIT (1988). For full text of the 2002 BIT see e.g., $<$ https://investmentpolicy.unctad.org/international-investment-agreements/treatyfiles/5130/download> accessed 1 November 2020.

47 See e.g. <https://icsid.worldbank.org/en/Pages/about/Database-of-Member-States.aspx> accessed 1 November 2020.

48 Bangladesh-India BIT (2009) was signed on $9^{\text {th }}$ February 2009 and it came into force on $7^{\text {th }}$ July 2011. For full text of the BIT see e.g., <https://investmentpolicy.unctad.org/international-investmentagreements/treaty-files/265/download> accessed 1 November 2020. 
Therefore Article 9(3) of Bangladesh-Thailand BIT (2002) particularly mentions national law as the applicable law for the dispute resolution, which is not found in other BITs singed by Bangladesh.

Bangladesh-Singapore BIT (2004) ${ }^{49}$ similar to many other BITs discussed above, in its Article 7 provides ICSID as only forum for ISDS along with a provision for alternative to arbitration namely, voluntary ADR (conciliation/mediation) ${ }^{50}$. Article 7 of the Bangladesh-Vietnam BIT $(2005)^{51}$ prescribes for domestic courts, international conciliation, ICSID and UNCITRAL as forums for ISDS and the relationship between these forums are 'fork on the road'. Bangladesh-India BIT $(2009)^{52}$ in its Article 9 provides for ISDS. Article 9(2) (b) refers to conciliation under UNCITRAL. The means of forums for arbitration it refers to domestic courts of the host state, ICSID and UNCITRAL without suggesting any reference between these forums. Article 12(2) of the BIT provides for essential security exception clause in case of extreme emergency. The language of the ISDS provision in Bangladesh-India BIT (2009) is quite different than the standard clauses drafted in the other BITs signed Bangladesh as it elaborately articulates the step by step process of ISDS forums under the treaty. ${ }^{53}$ Similar approach is found in Bangladesh-Denmark BIT $(2009)^{54}$ in its

49 Bangladesh-Singapore BIT (2004), signed $24^{\text {th }}$ June 2004 and came into force on $19^{\text {th }}$ November, 2004. For full text of the BIT see e.g., <https://investmentpolicy.unctad.org/international-investmentagreements/treaty-files/4885/download>accessed 1 November 2020.

50 Article 7(2) of Bangladesh Singapore BIT (2004) Ibid.

51 Bangladesh -Viet Nam BIT (2005) signed $1^{\text {st }}$ May, 2005 and yet to come into force. For full text of the BIT see e.g., <https://investmentpolicy.unctad.org/international-investment-agreements/treatyfiles/5131/download $>$ accessed 1 November 2020.

52 Bangladesh-India BIT 2009 (n 48).

53 Article 9 of Bangladesh India BIT (2009) ibid, reads:

"(1) Any dispute between an investor of one Contracting Party and the other Contracting Party in relation to an investment of the former under this Agreement shall, as far as possible, be settled amicably through negotiations between the parties to the dispute.

(2) Any such dispute which has not been amicably settled within a period of six months may, if both Parties agree, be submitted:

(a) for resolution, in accordance with the law of the Contracting Party which has admitted the investment to that Contracting Party's competent judicial, arbitral or administrative bodies; or

(b) to the international conciliation under the Conciliation Rules of the United Nations Commission on International Trade Law.

(3) Should the Parties fail to agree on a dispute settlement procedure provided under paragraph (2) of this Article or where a dispute is referred to conciliation but conciliation proceedings are terminated other than by signing of a settlement agreement, the dispute may be referred to Arbitration. The Arbitration procedure shall be as follows:

(a) If the Contracting Party of the Investor and the other Contracting Party are both parties to the Convention on the Settlement of Investment Disputes between States and Nationals of other States, 1965 and the investor consents in writing to submit the dispute to the International Centre for the Settlement of Investment disputes such a dispute shall be referred to the Centre; or 
Article 9 which prescribes forums for ISDS are domestic court of the host state, ICSID, UNCITRAL, ICC and other forums as well, without clearly suggesting the relation between these prescribed forums.

\subsection{BITs of the Fourth Decade (from 2010-2020)}

This is the decade when the current government came to power in 2009 and put attraction of FDI as one of its top priority. Accordingly, the government has taken different initiatives to attract FDI flow in the country. Therefore, since attraction of FDI was one of the major national targets of the government one could easily expect that there would be a proliferation of BITs in Bangladesh as it was evidenced in other developing countries. However, in reality Bangladesh signed only three BITs during this period. Whether that shows a rather cautious step by Bangladesh in signing BITs is difficult to say, as two of these BITs are merely reproduction of the previous BITs signed by Bangladesh. Article 9 of Bangladesh-UAE BIT (2011) ${ }^{55}$ states about ISDS provision. Article 9(3)(a) requires exhausting of local remedies before going to an international forum. ${ }^{56}$ It only refers to ICSID as a forum for investor state dispute and therefore the relationship between the two prescribed forums is "local remedies first".

(b) If both parties to the dispute so agree, under the International Centre for the Settlement of Investment Disputes Additional Facility for the Administration of Conciliation, Arbitration and Fact-Finding proceedings governed by Additional Facility Rules, 1979; or

(c) To an ad hoc arbitral tribunal by either party to the dispute in accordance with the Arbitration Rules of the United Nations Commission on International Trade Law, 1976, subject to the following modifications:

(i) The appointing authority under Article 7 of the Rules shall be the President, the VicePresident or the next senior Judge of the International Court of Justice, who is not a national of either Contracting Party. The third arbitrator shall not be a national of either Contracting Party.

(ii) The parties shall appoint their respective arbitrators within two months.

(iii) The arbitral award shall be made in accordance with the provisions of this Agreement and shall be binding for the parties in dispute.

(iv) The arbitral tribunal shall state the basis of its decision and give reasons upon the request of either party.

(4) Neither Contracting Party shall pursue through diplomatic channels any dispute submitted to a body or conciliation forum under paragraph(2), or referred to arbitration under paragraph (3) until the proceedings have terminated and a contracting Party has failed to abide by or to comply with the award or decision rendered by such body or conciliation Forum or Arbitration Forum."

54 Bangladesh-Denmark BIT (2009) signed $5^{\text {th }}$ November, 2009 and came into force on $27^{\text {th }}$ March 2013. For full text of the BIT see e.g., <https://investmentpolicy.unctad.org/international-investmentagreements/treaty-files/5125/download> accessed 1 November 2020.

55 Bangladesh-UAE BIT (2011) signed $17^{\text {th }}$ January, 2011 and yet to come into force. For full text of the BIT see e.g., <https://investmentpolicy.unctad.org/international-investment-agreements/treatyfiles/276/download> accessed 1 November 2020.

56 Article 9(3)(a) With respect to paragraph 1 of this Article, if the dispute cannot be settled amicably within the period of three months, the Parties to the dispute should pursue the following procedures: a) If the dispute is not amicably settled within three(3) months as referred to in paragraph 1 then it shall be filled to the competent authorities or arbitration centres thereof, constituted under the laws of the Contracting Party, in whose territory the investment was made exhausting all local remedies; 
The other BIT signed during this period, the Bangladesh-Turkey BIT (2012) in its Article 10 stipulates the ISDS provision. ${ }^{57}$ The text of the treaty is drafted in the most common terms and does not include any other specific features that some other ISDS provisions include. It does provide for referring the dispute to the domestic courts of the host state ${ }^{58}$ and prescribes ICSID and UNCITRAL as forums for ISDS and it does not provide any alternative to arbitration. Article 10(4)(a) states that investments which only have acquired prior permission can enjoy the benefits under this section of ISDS. ${ }^{59}$ Thus, relationship between the two forums are 'fork in the road'. One positive feature of this BIT is that, in its Article 4 which states about protection of public health and environment, prescribes for exclusion of policy areas from ISDS $^{60}$ thereby the only BIT signed by Bangladesh which reflects few features of new generation of BITs. The text of Bangladesh-Cambodia BIT (2014) is not available in public domain therefore unable to make any comment on the ISDS provision in this particular BIT. It is to be noted that Bangladesh has not signed any BIT with any Latin American or African countries, but now considering to sign FTA with African countries. ${ }^{61}$

\subsection{Treaties with Investment Provisions (TIPs)}

In this discussion it is also pertinent to mention that, apart from the BITs Bangladesh also has signed some multilateral treaties on trade, commerce and investment having provisions on investment protection which are knows as Treaties with Investment provisions (TIPs). Some of these are the UN's Economic and Social Commission for Asia and the Pacific came up with this Framework Agreement on the Promotion,

57 Bangladesh-Turkey BIT (2012) ( n 24).

See e.g., Article 10(2) (a) of Bangladesh-Turkey BIT (2012) Ibid., states,

"2. If these disputes, cannot be settled amicably within six (6) months following the date of the written notification mentioned in paragraph 1 , the disputes can be submitted, as the investor may choose, to: (a) the competent court of the Contracting Party in whose territory the investment has been made, or ..."

59 Bangladesh-Turkey BIT (2012) Ibid, Article 10(4.) states,

"Notwithstanding the provisions of paragraph 2 of this Article;

(a) only the dispute arising directly out of investment activities which have obtained necessary permission, if any, in conformity with the relevant legislation of both Contracting Parties on foreign capital, and that effectively started shall be subject to be jurisdiction of the International Center for Settlement on Investment Disputes (ICSID) or any other international dispute settlement mechanism as agreed upon by Contracting Parties.

60 Bangladesh-Turkey BIT (2012) Ibid, Article 4 (Protection of Public Health and Environment) states, "1. A Contracting Party shall not waive or otherwise derogate from its national public health and environmental policies as an encouragement or otherwise, to the establishment, acquisition, expansion, operation, management, maintenance, use, enjoyment and sale or other disposal of an investment of an investor of the other Contracting Party.

2. Each Contracting Party shall reserve the right to exercise all legal measures in case of loss, destruction or damages with regard to its public health or life or the environment by investments of the investors of the other Contracting Party.

61 See e.g., <https://thefinancialexpress.com.bd/trade/bd-plans-signing-ftas-with-african-countries$1593836160>$ accessed 1 November 2020. 
Protection and Liberalization of Investment between Asia-Pacific Participating States in 2009 (shortly known as the Asia-Pacific Trade Agreement (APTA) (2009) ${ }^{62}$, yet to come into force), the South Asian Free Trade Area (SAFTA) Accord 2004 ${ }^{63}$ and the Bangladesh-EC Cooperation Agreement (2000),${ }^{64}$ none of these three TIPS contain any provision on ISDS. The only TIPs signed by Bangladesh that contains ISDS is the OIC Investment Agreement (1981) ${ }^{65}$, which in its Article 17 provides for ISDS suggesting scope for conciliation and arbitration. ${ }^{66}$ It is to be noted that, eight BITs signed by

62 APTA Investment Agreement (2009) singed on $15^{\text {th }}$ December 2009. The treaty is yet to come into force. The member states of the treaty are China, Republic of Korea, Lao People's Democratic Republic and Sri Lanka. For full text of the treaty see, e.g., <https://investmentpolicy.unctad.org/ international-investment-agreements/treaty-files/2591/download> accessed 1 November 2020. It is also to be noted here that this treaty does not overlap with other treaties concluded between the state parties, such as the China-Republic of Korea FTA (2005), China-Japan-Republic of Korea Trilateral Investment Agreement (2012), ASEAN-China Investment Agreement (2009) and ASEAN-Republic of Korea Investment Agreement (2009).

63 South Asian Free Trade Accord (2004) was signed on $6^{\text {th }}$ January 2004 and came into force on $1^{\text {st }}$ January 2006. This is a trade agreement between all South Asian Association for Regional Cooperation (SARRC) countries, namely, Afghanistan, Bangladesh, Bhutan, India, Maldives, Nepal, Pakistan and Sri Lanka. For full text of SAFTA see e.g., <https://investmentpolicy.unctad.org/ international-investment-agreements/treaty-files/2671/download> accessed 1 November 2020.

Cooperation Agreement between the European Community and the People's Republic of Bangladesh on Partnership and Development (Bangladesh EC Cooperation Agreement) was signed on $22^{\text {nd }}$ May 2000 and came into force on $1^{\text {st }}$ March 2001. For full text of the treaty see., e.g., $<$ https://investmentpolicy.unctad.org/international-investment-agreements/treaty-

files/2399/download https://investmentpolicy.unctad.org/international-investment-agreements/treatyfiles/3088/download> accessed 1 November 2020.

65 Agreement on Promotion, Protection and Guarantee of Investments amongst the Member States of the Organization of the Islamic Conference (OIC) was signed on $5^{\text {th }}$ June 1981 and it came into force on February 1988. For full text of OIC Investment Agreement see e.g., see https://investmentpolicy. unctad.org/international-investment-agreements/treaty-files/2399/download Accessed 1 November 2020.

66 Article 17 of OIC Investment Agreement, ibid, reads as follows

"1. Until an Organ for the settlement of disputes arising under the Agreement is established, disputes that may arise shall be entitled through conciliation or arbitration in accordance with the following rules and procedures:

1. Conciliation

a) In case the parties to the dispute agree on conciliation, the agreement shall include a description of the dispute, the claims of the parties to the dispute and the name of the conciliator whom they have chosen. The parties concerned may request the Secretary General to choose the conciliator. The General Secretariat shall forward to the conciliator a copy of the conciliation agreement so that he may assume his duties.

b) The task of the conciliator shall be confined to bringing the different viewpoints closer and making proposals which may lead to a solution that may be acceptable to the parties concerned. The conciliator shall, within the period assigned for the completion of his task, submit a report thereon to be communicated to the parties concerned. This report shall have no legal authority before a court should the dispute be referred to it.

2. Arbitration

a) If the two parties to the dispute do not reach an agreement as a result of their resort to conciliation, or if the conciliator is unable to issue his report within the prescribed period, or if the two parties do not accept the solutions proposed therein, then each party has the right to resort to the Arbitration Tribunal for a final decision on the dispute. 
Bangladesh, discussed above co-exists the OIC Investment Agreement of 1981. Needless "to mention these are the ones with the countries who are also OIC member states and signatories of the OIC Investment Agreement (1981). ${ }^{67}$

\section{Summary of the features of ISDS provisions in BITs of Bangladesh}

With very few exceptions, every BIT that Bangladesh has singed predominantly provides for an enforcement mechanism of ISDS, generally conferring the rights of the foreign investors to have the right to take the recourse to international arbitration against Bangladesh on different forums by sidestepping the country's domestic court system. ${ }^{68}$ From the discussion made above it is difficult to conclude that all the ISDS provisions are of similar verbatim, some of which are of course. But nevertheless, all these ISDS provisions have their own distinct feature in terms of articulation and mentioning the forums, though there are definitely an overarching similarity between these BITs. However, from the discussion made above based on the articulation of the ISDS provisions in Bangladesh BITs the features of these clauses can be summarized as follows:

b) The arbitration procedure begins with a notification by the party requesting the arbitration to the other party to the dispute, clearly explaining the nature of the dispute and the name of the arbitrator he has appointed. The other party must, within sixty days from the date on which such notification was given, inform the party requesting arbitration of the name of the arbitrator appointed by him. The two arbitrators are to choose, within sixty days from the date on which the last of them was appointed arbitrator, an umpire who shall have a casting vote in case of equality of votes. If the second party does not appoint an arbitrator, or if the two arbitrators do not agree on the appointment of an Umpire within the prescribed time, either party may request the Secretary General to complete the composition of the Arbitration Tribunal.

c) The Arbitration Tribunal shall hold its first meeting at the time and place specified by the Umpire. Thereafter the Tribunal will decide on the venue and time of its meetings as well as other matters pertaining to its functions.

d) The decisions of the Arbitration Tribunal shall be final and cannot be contested. They are binding on both parties who must respect and implement them. They shall have the force of judicial decisions. The contracting parties are under an obligation to implement them in their territory, no matter whether it be a party to the dispute or not and irrespective of whether the investor against whom the decision was passed is one of its nationals or residents or not, as if it were a final and enforceable decision of its national courts."

67 These includes Bangladesh-Indonesia BIT (1998) ((n 34); Bangladesh-Republic of Iran BIT (2001) ((n45); Bangladesh- Malaysia BIT (1994) ((n 29); Bangladesh-Pakistan BIT (1995) text not available, Bangladesh-Turkey BIT (1987) (n(23); Bangladesh-Turkey BIT (2012) (n 24); Bangladesh-UAE BIT (2011) Supra note 55; and Bangladesh-Uzbekistan BIT (2000) Supra note 40. For a list of other BITs signed by the other member states, as well as different FTAs and other Investment related Agreements that coexists with the OIC Investment Agreement (1981) see e.g., https://investmentpolicy.unctad.org/international-investment-agreements/treaties/treaties-withinvestment-provisions/3092/oic-investment-agreement-1981- Accessed 1 November 2020. 
(a) BITs which provide an all comprehensive ISDS clause which prescribes all possible forums for an investor-state dispute;

(b) BITs which provides limited scope for ISDS forums, including either only the local remedies or specific forum like that of the ICSID as the only option for an investor-sate dispute.

(c) BITs that categorically mentions the relation between the forums (i.e. fork on the road).

(d) BITs that categorically mentions "local remedies first"

(e) BITs which provides exception to ISDS ambit (like exception to tax or expropriation related disputes from ISDS)

(f) BITs which provides specific requirement as to the appointment or nationality of the arbitrator

(g) BITs which provides for non-precluded measures (NPMs) or general exceptions from the scope of the ISDS claims.

\section{Conclusion}

With the proliferation of the BIT program with ISDS provisions, also has significantly led to the increasing number of investor state dispute. ${ }^{69}$ In comparison to other developing countries the number of investors claims against Bangladesh is rather low. But with the increase of flow of FDI, there is every possibility that the number of ISDS claims against Bangladesh is likely to sufficiently increase in the coming days. Past experience of ISDS claims made against host developing countries says that foreign investors have made their claims on wide range of issues of regulatory measures covering from national security, public interest, environmental protection, public health to taxation policies. A successful ISDS claim also means that, awarding damages to the foreign investor in compliance with the arbitral award is actually making that payment from the tax payer's money to the foreign investors. ${ }^{70}$ The amount of compensation awarded by the arbitral tribunals in the disputes that arose out of Argentine financial crisis, ${ }^{71}$ recent Spanish debt crisis ${ }^{72}$ and

\footnotetext{
See UNCTAD Report on ISDS, (n 5).

Ranjan (n 1) 11.

See generally e.g., Rumana Islam, The Fair and Equitable Treatment Standard (FET) in International Investment Arbitration: Developing Countries in Context (Springer 2018) Ch.6;

72 García-Castrillón CO, Spain and Investment Arbitration: The Renewable Energy Explosion, $<$ https://www.cigionline.org/publications/spain-and-investment-arbitration-renewable-energyexplosion> accessed 14 August 2020; López-Rodríguez AM and Navarro P (2016), Investment Arbitration and EU Law in the Aftermath of Renewable Energy Cuts in Spain, 25 Eur. Energy \& Envtl. L. Rev. 2; Behn D and Fauchald O Kristian, (2015) Governments under Cross-Fire: Renewable Energy and International Economic Tribunals, 12 Manchester J. Int'l Econ. L. 117-139.
} 
the disputes that arose against Egypt as an aftermath effect of the Arab Spring crisis ${ }^{73}$ are good example of such pain that a country needs to bear to satisfy the claims of the foreign investor.

The danger of the host developing states is that they get caught for wide range of their sovereign decisions even if they have exercised such powers for the sake of public interest is due to the fact that the investor protection standards are drafted in vaguely in the texts of the treaties (for example the FET standard) ${ }^{74}$ and due to the fact that, the ISDS provisions are also drafted vaguely with a broad net. ${ }^{75}$ The very notation of the idea of devising the BIT program by the West was to ensure that certain conditions were imposed upon the regulatory behaviours of the host state and accordingly protect the foreign investors and their investments from the undue and arbitrary interferences by the host states. ${ }^{76}$ It is interesting to note that despite the attraction of FDI being the top priority over the last decade if we look into number of BITs concluded by Bangladesh are very few. Even in terms of change of approach Bangladesh rather remained silence and in a way failed to alter its BIT regime in response to the changing Global South context where there is a dramatic shift of attitude from foreign investor protection to host state priority, even if we take the example of neighbouring India, who has come up with their own Indian Model BIT $(2016)^{77}$ putting host state's interest as its core feature. Thus, there is a strong need to review the existing BIT regime of the country, and specially the ambit of the scope of the ISDS provisions contained in those BITs, with an aim to reconsider its conventional international treaty making practice. Bangladesh needs to align its future of investment treaty making practice with the demands set forth by the current trends on recognizing the host state's need to adopt the scope of the ISDS provisions read with other general exceptions and NPM clauses in the BIT that would address the regulatory freedom for public interest manifestations of Bangladesh as the host state.

73 Vaughan J (2013), Arbitration in the Aftermath of the Arab Spring: From Uprisings to Awards, The Ohio State Journal of Dispute Resolution 28(2) at pp. 491-518; An Arab Spring of treaty arbitration? <https://vannin.com/press/pdfs/arab-spring-of-treaty.pdf> accessed 14 August 2020>.

74 See generally, Islam, (n 71).

75 See e.g., Ranjan (n 1, 15); Suzanne Spears 'The Quest For Policy Space in a New Generation of International Investment Agreements', 13 Journal of International Economic Law (2010), 1040; Ma Coldfelter 'The Adaptation of States to the Changing World of Investment Protection through Model BITs' 24 ICSID Review of Foreign Investment Law (2009) 165.

76

77

Indian Model BIT (2016) for full text <https://investmentpolicy.unctad.org/international-investmentagreements/treaty-files/3560/download>accessed 1 November 2020. 
